\title{
DISTRIBUTION OF FLUORINE BETWEEN MINERALS AND GLASS IN LAMPROITES, LAMPROPHYRES AND KAMAFUGITES: IMPLICATIONS FOR THE ROLE OF F IN DEEP MANTLE-DERIVED MAGMAS.
}

\author{
Edgar, ${ }^{(1)}$ A.D.; Vukadinovic, ${ }^{(1)}$ D. and Lloyd, ${ }^{(2)}$ F.E. \\ (1)Department of Geology, University of Western Ontario, London, Ontario, Canada, N6A 5B7.; (2)Department of \\ Geology, University of Reading, Reading, U.K. RG6 2AB..
}

Lamproites, lamprophyres and kamafugites are among the most $\mathrm{F}$-rich igneous rocks. With increasing $\mathrm{K}_{2} \mathrm{O}$ contents $(>1$ wt. $\% \mathrm{~K}_{2} \mathrm{O}$ ) the average $\mathrm{F}$ contents in kamafugites, type 1 kimberlites, olivine lamproites, lamprophyres and leucite lamproites are $0.1,0.2,0.25,0.3$ and 0.5 wt. $\frac{0}{0}$ respectively.

The higher abundances of $\mathrm{F}$ in these deep mantle-derived magmas relative to magmas originating at shallower levels, suggests that $F$ may be very important in ultrapotassic magma genesis. Among the roles proposed for $F$ is that the speciation and amount of $\mathrm{F}$ may affect $\mathrm{fO}_{2}$ buffering in the mantle that consequently controls differentiation and other important petrogenetic hypotheses (e.g. Foley et al., 1986). These hypotheses depend on the availability of $F$ in mantle reservoirs and whether on partial melting $F$ is partitioned into melt or solid phases. Data on the $F$ contents of likely mineral reservoirs (phlogopite, apatite and amphibole) in mantle-derived xenoliths (Aoki et al., 1981; Smith et al., 1981) are limited and where available indicate that $F$ is not particularly abundant in these minerals. Experiments to determine partitioning of $F$ under mantle conditions are also few (Edgar and Arima, 1985) and time consuming. In the present study the distribution of $F$ between minerals and glass in lamproitic, lamprophyric and kamafugitic rocks was determined and compared to the abundance and distribution of $F$ with similar data from mantle-derived xenoliths from the kamafugitic provinces of south-west Uganda and the West Eifel of Germany.

Distribution of $\mathrm{F}$ between phlogopite, amphibole, apatite and glass in 26 lamproites from Leucite Hills, West Kimberly, Smoky Butte, Prairie Creek and Gaussberg is very complex both within and between lamproite localities, with some mineral reservoirs showing distinctly different trends in different localities, e.g. phlogopite in Leucite Hills and West Kimberly lamproites has increasing and decreasing $F$ from core to rim respectively. Generally $F$ is most abundant in phlogopite and apatite relative to amphibole and glass. In evolved glasses $F$ may be absent. With increasing evolution, $F$ decreases in the rocks and in its amphibole and glass. Fluorine appears to be related to the $\mathrm{Ba}$ contents in apatite and glass in some lamproites.

Fluorine in minerals and glass in kamafugitic rocks from south-west Uganda and West Eifel, Germany, is only slightly lower than in lamproites and shows similar trends. Phlogopites in the West Eifel kamafugites have high $\mathrm{F}$ and $\mathrm{BaO}$ contents whereas the phlogopites from Ugandan kamafugites 
have lower $\mathrm{F}$ and $\mathrm{BaO}$. Glass in kamafugites from West Eifel and Uganda has low $F$ contents and shows no trend in $F$ with evolution as determined by MG no., unlike that of glass in lamproites from Leucite Hills in which $F$ decreases with decreasing $M G$ no. The $F$ in amphibole in the Ugandan rocks is higher than that of amphibole in most lamproites.

In West Eifel mantle xenoliths $F$ in phlogopite is very low ( $<0.5$ wt. $\%)$ whereas apatite in a Ugandan xenolith averages 1.3 wt. $\frac{\circ}{0}$ luorine. Fluorine in glass in both west Eifel and Ugandan xenoliths is low ( $<0.5$ wt. \%). This suggests that if glass represents metasomatizing agents (Edgar et al., 1989) that these agents did not have sufficient $F$ to provide the levels of abundance observed in the lava. Also, the very low $F$ contents of the mineral reservoirs in the xenoliths implies that observed abundances of $\mathrm{F}$ in these kamafugites could not have been derived solely by partial melting of the mantle source.

The distribution of $\mathrm{F}$ between phases in kamafugitic lavas is similar to that observed in lamproites. Analyses from individual rocks indicate that $F$ is richest in phlogopite followed by apatite, amphibole and glass. This is generally true for both lamproites and kamafugites. Fluorine contents in glass from kamafugites are usually less than 1 wt. $\frac{\circ}{0}$ and approximately an order of magnitude smaller than $\mathrm{F}$ abundances in volatile-bearing phases within the same rock, suggesting that $F$ is a compatible element.

Fluorine contents in apatite and phlogopite in minettes from Hopi-Navajo, U.S.A., are generally lower relative to those in kamafugitic rocks and show no significant trends.

The complex distribution of $F$ between phlogopite, apatite, amphibole and glass in lamproites, lamprophyres and kamafugites does not allow determination of partition coefficients because of the inability to clearly establish mutual chemical equilibrium between F-bearing phases, possibly due to changes in parameters such as $\mathrm{fO}_{2}$ during evolution, or other variables. This study suggests that $F$ preferentially enters solid rather than liquid phases in these magmas and that $F$ is not abundant in minerals of mantle xenoliths in kamafugitic hosts. Fluorine in mantle mineral reservoirs is likely to be insufficient to provide the high $\mathrm{F}$ contents for these ultrapotassic magmas. The possibility that these magmas derive their high $F$ contents during degassing on ascent rather than during partial melting is considered.

\section{REFERENCES}

AOKI, K., ISHIWAKA, K. and KANISAWA, S. (1981) Fluorine geochemistry of basaltic rocks from continental and oceanic regions and their petrogenetic applications. Contributions Mineralogy petrology 76, 53-59. 
EDGAR, A.D. and ARIMA, M. (1985) Fluorine and chlorine contents of phlogopites crystallizing from ultrapotassic rock compositions in high pressure experiments:

implications for halogen reservoirs in source regions. American Mineralogist 70, 529-536.

EDGAR, A.D., LLOYD, F.E., FORSYTH, D.M. and BARNETT, R.L. (1989) Origin of glass in upper mantle xenoliths from the Quaternary volcanics of Gees, West Eifel, Germany. Contributions Mineralogy Petrology 103, 277-286.

FOLEY, S.F, TAYLOR, W.R. and GREEN, D.H. (1986) The role of fluorine and oxygen fugacity in the genesis of the ultrapotassic rocks. Contributions Mineralogy Petrology 94, 183-192.

SMITH, J.V., DELANEY, J.S., HERVIG, R.L and DAWSON, J.B. (1981) Storage of $\mathrm{F}$ and $\mathrm{Cl}$ in the upper mantle: geochemical implications. Lithos 14, 133-147. 